\title{
Siklofosfamid Nedenli Kan Hücreleri ve Kemik İliği Toksisitesi Üzerine Escinin Koruyucu Etkilerinin Sıçanlarda Araştırılması
}

\author{
Mustafa Cengiz ${ }^{1 *}$, Adnan Ayhanc1 $^{2}$, Hatice Mehtap Kutlu ${ }^{3}$ \\ Geliş / Received: 20/01/2020 \\ Revize / Revised: 30/06/2020 \\ Kabul / Accepted: 01/07/2020

\section{öZ}

Siklofosfamid (CPM), metabolitleri nedeniyle kanserli hücrelerin yanı sıra sağlıklı dokularda da toksisiteye neden olan yaygın olarak kullanılan bir antineoplastik ilaçtır. Bu ilacın ana dezavantajı miyelosupresyondur. Escin (ES), antioksidan, antienflamasyon ve anti-ödem gibi biyolojik özelliklere sahip doğal bir triterpenoid saponin karışımıdır. Bu çalışma, CPM'nin kan hücreleri ve kemik iliği üzerindeki toksik etkileri üzerine ES'nin olası etkilerini araştırmayı amaçlamaktadır. Spraque Dawley erkek sıçanlar, kontrol grubu, $200 \mathrm{mg} / \mathrm{kg} \mathrm{CPM}, 10 \mathrm{mg} /$ kg ES ve CPM+ES olmak üzere 4 farklı gruba ayrıldı. Tüm gruplardaki sıçanlar enjeksiyonlardan 1 gün sonra kesildi. Hayvanlar anestezi altında kesildikten sonra kemik iliği ve kan örnekleri alındı. CPM grubunda eritrosit, hemoglobin, hematokrit, lökosit (\% 97), trombositler (\% 45) ve kemik iliği hücreleri (\% 93.6) sayısında kontrol grubuna göre bir azalma vardı. Tersine, ES + CPM' grubundaki kan hücreleri (eritrosit, hemoglobin, hematokrit, lökosit ve trombositler) ve kemik iliği hücreleri CPM verilen grup ile karşılaş̧ırıldığında artmıştır. Sonuçlarımız, ES ile sıçanların tedavi edilmesinin, CPM'nin kan hücreleri ve kemik iliği üzerindeki toksik etkilerini azaltmaya yardımcı olabileceğini göstermektedir.

Anahtar Kelimeler- Escin, Sitoprotektif, Siklofosfamid, Hematotoksisite, Sıçan

1*Sorumlu yazar iletişim: mustafacengizogu@gmail.com (https://orcid.org/0000-0002-6925-8371)

Department of Mathematics and Science Education, Siirt University, Siirt, Turkey

2illetişim: aayhanci@ogu.edu.tr (https://orcid.org/0000-0003-4866-9814)

Department of Biology, Eskisehir Osmangazi University, Eskisehir, Turkey

3iletişim: hmkutlu@eskisehir.edu.tr (https://orcid.org/0000-0002-8816-1487)

Department of Biology, Eskisehir Tecnical University, Eskisehir, Turkey 


\title{
Investigation into the Protective Effects of Escin on Blood Cells and Cyclophosphamide-Induced Bone Marrow Toxicity in Rats
}

\begin{abstract}
Cyclophosphamide (CPM) is an extensively used antineoplastic drug that induces toxicity in the health cell because of its metabolites. The main disadvantage of this drug is myelosuppression. Escin (ES) is a natural mixture of triterpenoid saponins that has biological properties such as antioxidant, anti-inflammation, and anti-edematous. The present study aims to investigate the possible effects of ES upon the toxic effects of CPM on blood cells and bone marrow. Spraque Dawley male rats were chosen and categorized into 4 different groups, including the control group, $200 \mathrm{mg} / \mathrm{kg} \mathrm{CPM,} 10 \mathrm{mg} / \mathrm{kg}$ ES and ES+CPM. Rats in all groups were discontinued 1 day after injections. After the animals were cut under anesthesia, bone marrow and blood samples were collected. A fall in the number of erythrocyte, hemoglobin, hematocrit, leukocyte (97\%), platelets (45\%), and bone marrow cells $(93.6 \%)$ was seen in the CPM group. Conversely, blood cells (erythrocyte, hemoglobin, hematocrit, leukocyte, and platelets), as well as bone marrow cells in ES + CPM had increased by comparison with CPM. Our results show that treating rats with a selected dose range of ES may help decrease the toxic effects of CPM upon blood cells and bone marrow.
\end{abstract}

Keywords- Escin, Cytoprotective, Cyclophosphamide, Hematotoxicity, Rats 


\begin{tabular}{|c|c|c|}
\hline & $\begin{array}{l}\text { BŞEÜ Fen Bilimleri Dergisi } \\
7(2), 730-738,2020\end{array}$ & $\begin{array}{r}\text { BSEU Journal of Science } \\
\text { DOI: } 10.35193 / \text { bseufbd.677193 }\end{array}$ \\
\hline & & 58-7575 (http://dergipark.gov.tr/bseufbd) \\
\hline
\end{tabular}

\section{INTRODUCTION}

Cyclophosphamide (CPM), renowned as a cytotoxic agent, is not just an anti-neoplastic but also an immunosuppressive agent widely used in treating many cancers. However, it a prodrug that has got to be metabolized in the living system to form reactive components like acrolein and phosphoramide mustard [1]. Previous studies have shown these toxic metabolites to decrease lung microsomal enzyme activities, in addition to preventing mammals' antioxidant defense system from functioning properly [2]. The fact is that long-standing CPM treatment may result in side-effects like marked myelosuppression [3], known as a potentially toxic and a dose-limiting effect of CPM. By acting not only on cyclic but also on intermitotic cells, CPM contributes to the cross-linking of DNA, thus inhibiting the synthesis of DNA and causing an overall reduction in immune component cells [4]. Apart from its carcinogenic and teratogenic potentials, CPM also holds recognized toxic effects upon the heart, bladder, and hematopoietic system. It may also cause leucopenia and reduce the platelet number [5]. According to many studies, CPM exposure increases intracellular reactive oxygen species (ROS) production, suggesting that biochemical plus physiological disorders may be caused by oxidative stress [6]. Studies into mammals have revealed that CPM may also give severe harm to the blood-forming tissues of bone marrow. Also, it may temporarily cause a fall in circulating PMNs (polymorphonuclear neutrophils) and so affect our innate immune system. Furthermore, CPM can result in a decrease in microsomal enzyme activity and weaken our antioxidant defense system. This, in turn, weakens our specific immunity by directly depleting lymphoid tissues and keeping the host from giving an acceptable specific immune response [7].

Escin (ES) is known as a regular mixture of triterpene saponins, primarily comprising A, B, C, and D escin (Figure 1) [8]. We know of no less than 3 kinds of pharmacodynamic actions that are closely associated with ES, antioxidant and venotonic properties, as well as anti-edematous properties and anti-inflammatory activities [9, 10]. ES is usually preferred for patients with severe trauma injury as an effective anti-inflammatory and anti-edema agent. As for our study, the rats had been injected ES prior to CPM treatment to investigate the effects of ES on CPM-related hematotoxicity.

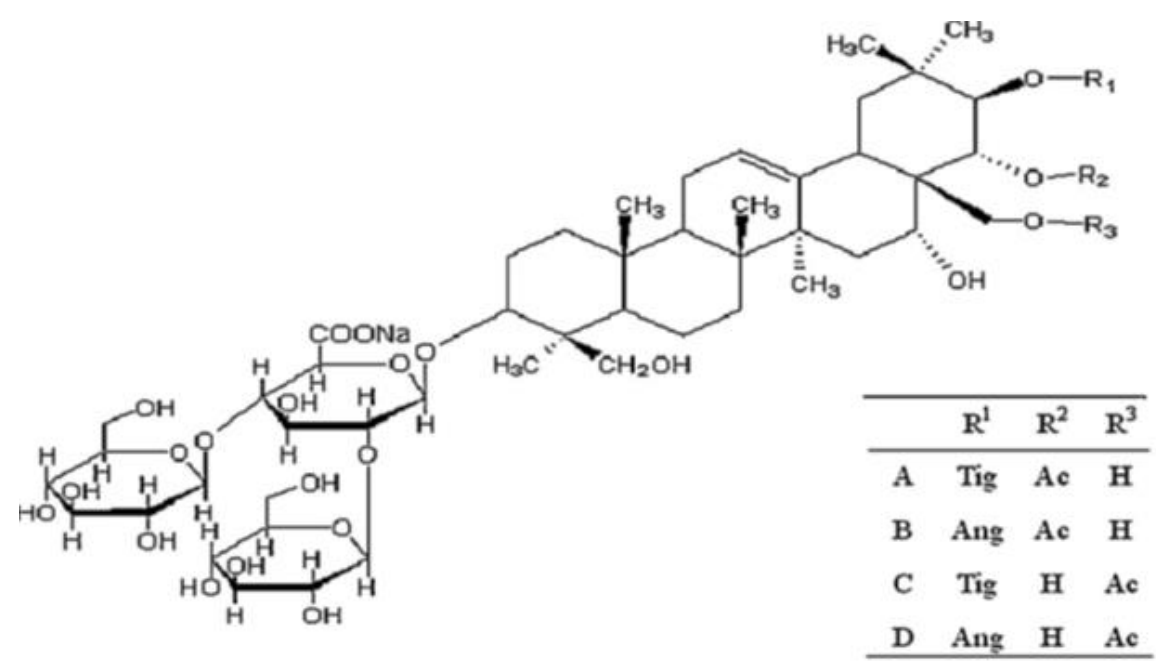<smiles>CC=C(C)C(C)=O</smiles><smiles>CC=C(C)C(=O)[N+](=O)[O-]</smiles><smiles></smiles>

Figure 1. The structure of ES 


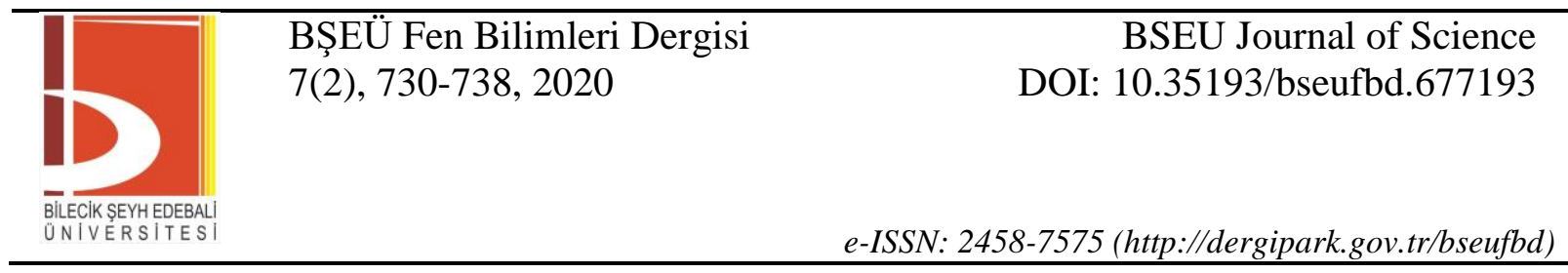

\section{MATERIAL AND METHODS}

\section{A. Materials}

Not only ES but also CPM was cultivated from Sigma. $500 \mathrm{mg}$ of SF had been dissolved in $25 \mathrm{~mL}$ saline in preparation for injection. As for the chemical injections, they were given to the rats intraperitoneally (i.p.) with sterile, disposable syringes subsequent to freshly-prepared solutions. In preparing the orally-given solution, 10 $\mathrm{mg} / \mathrm{kg}$ dose of ES was dissolved in $0.5 \mathrm{~mL}$ of distilled water.

\section{B. Treatment}

Our study was launched only after ethical approval had been obtained from the Experimental Animals Ethics Committee of Eskişehir Osmangazi University. The rats to be studied were obtained from the Public Health Center. Care was taken to feed the animals in a standard environment, with drinking water and standard food pellets prepared carefully. The rats were diligently kept under standard humidity (45-50\%), temperature (22 \pm $\left.2{ }^{\circ} \mathrm{C}\right)$, and light $(12 \mathrm{~h} \mathrm{light} / 12 \mathrm{~h}$ dark) conditions. Their weight was measured not only during the injection process but also before they were slaughtered in the determination of the dose to be applied. Injection of the second group that was given solely CPM was achieved on the very first day. The very next day, they were anesthetized. As to the group given both CPM and ES, the injection was achieved on the first day. Under ether anesthesia, we obtained the blood samples with aid of a cardiac puncture. The study animals were slaughtered on the second day. We flushed their bone marrow with saline into a test tube after both femurs had been dissected. A cell counter (Coulter) was used in counting the homogenized bone marrow, blood cells, and nucleated cells.

\section{Statistical Analyses}

The expression of the data of the animal experiments was achieved as the standard error of the mean $( \pm$ SEM). As for the analysis of the independent measurements and continuous data showing a normal distribution, One Way Anova was used. Furthermore, the Kruskal-Wallis test was used in scoring the variants showing an abnormal distribution. The differences in the experimental groups were regarded as significant if the $\mathrm{p}$-value was $<0.001$ and $<0.05$

\section{RESULTS}

The rise in the number of leukocytes, erythrocyte, hemoglobin, hematocrit, and platelet in the group given $10 \mathrm{mg} / \mathrm{kg}$ of ES was not of a statistical significance $(p>0.05)$. On the other hand, the rise in the number of bone marrow-nucleated cells was of statistical significance ( $p<0.01$ ). However, $200 \mathrm{mg} / \mathrm{kg}$ of CPM resulted in a $97 \%$ reduction in leukocyte cells when no other chemicals were added to the dose $(p<0.001)$. Injected along with CPM, $10 \mathrm{mg} / \mathrm{kg}$ of ES lowered leukocytes as much as 18\% ( $p<0.01)$ (Figure 2). Interestingly, platelets of rats given 200 $\mathrm{mg} / \mathrm{kg}$ of CPM alone decreased by $45 \%(p<0.001)$. As for the results of a combination of both CPM and ES, the number of thrombocytes decreased as much as $31 \%(p<0.05)$ (Figure 3$)$. Bone marrow-nucleated cells reduced as much as $93,6 \%$ once $200 \mathrm{mg} / \mathrm{kg}$ of CPM was injected $(p<0.001)$. In comparison with the respective three doses of CPM, $10 \mathrm{mg} / \mathrm{kg}$ of ES induced as much as $49 \%$ recovery in bone marrow-nucleated cell numbers (Figure 4). When used alone, CPM decreased the number of erythrocytes as much as $27 \%(p<0.01)$ (Figure 5). When given with a respective dose of CPM, $10 \mathrm{mg} / \mathrm{kg}$ of ES lowered leukocytes as much as $17 \%(p<0.01)$ (Figure 2). The number of hemoglobin and hematocrit in the animals given $200 \mathrm{mg} / \mathrm{kg}$ of CPM alone fallen as much as 19 and $23 \%$, respectively $(p<0.05)$. Given along with a respective dose of CPM, $10 \mathrm{mg} / \mathrm{kg}$ of ES enlarged the number of hemoglobin and hematocrit by 21 and \% $20(p>0.05)$ (Figures 6 and 7). 

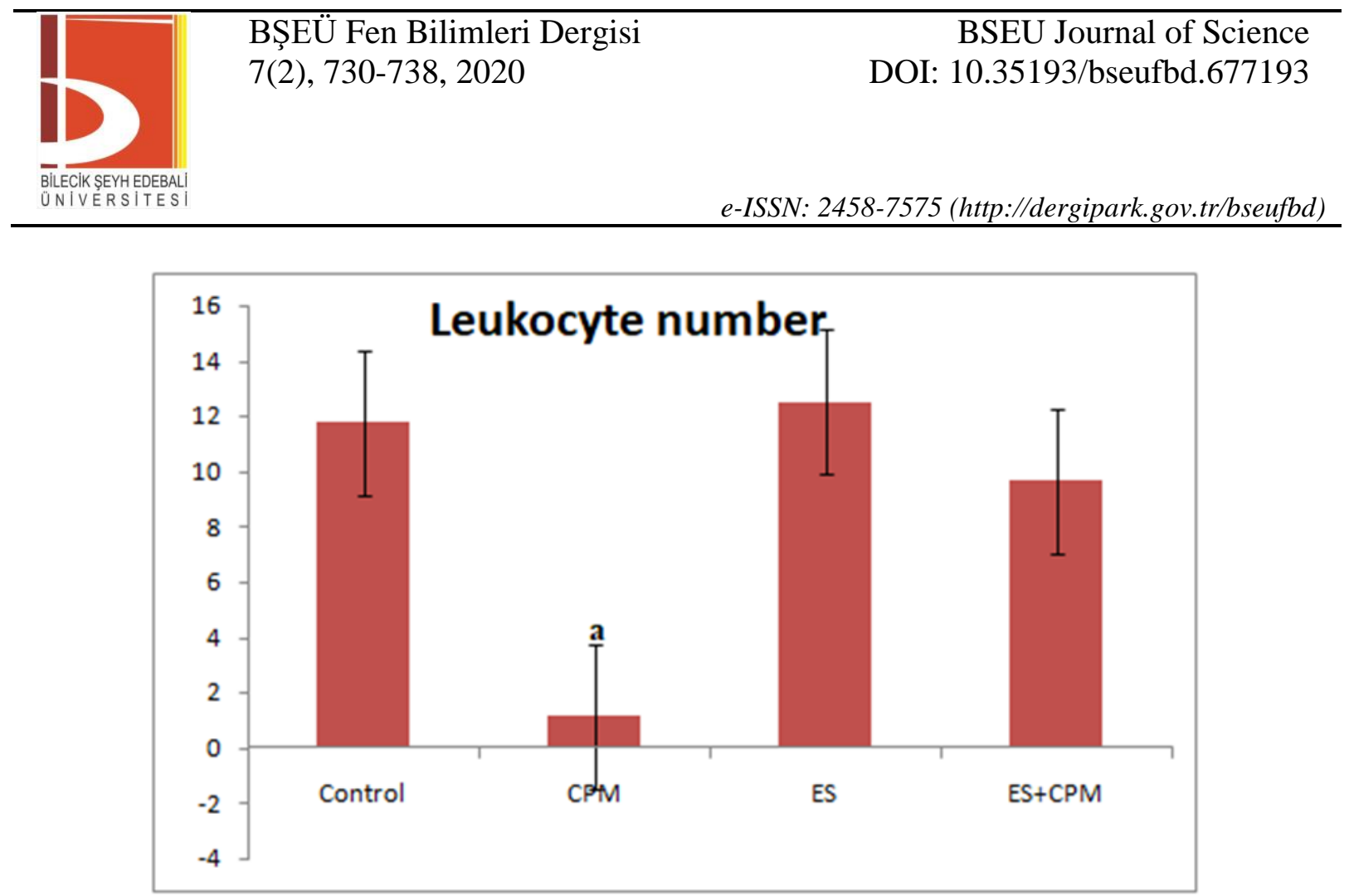

Figure 2. The number of leukocytes in the existence of all groups $\left(\mathrm{X} 10^{3} / \mu \mathrm{L}\right) .{ }^{\mathrm{a}} p<0.001$ significant difference compared to control

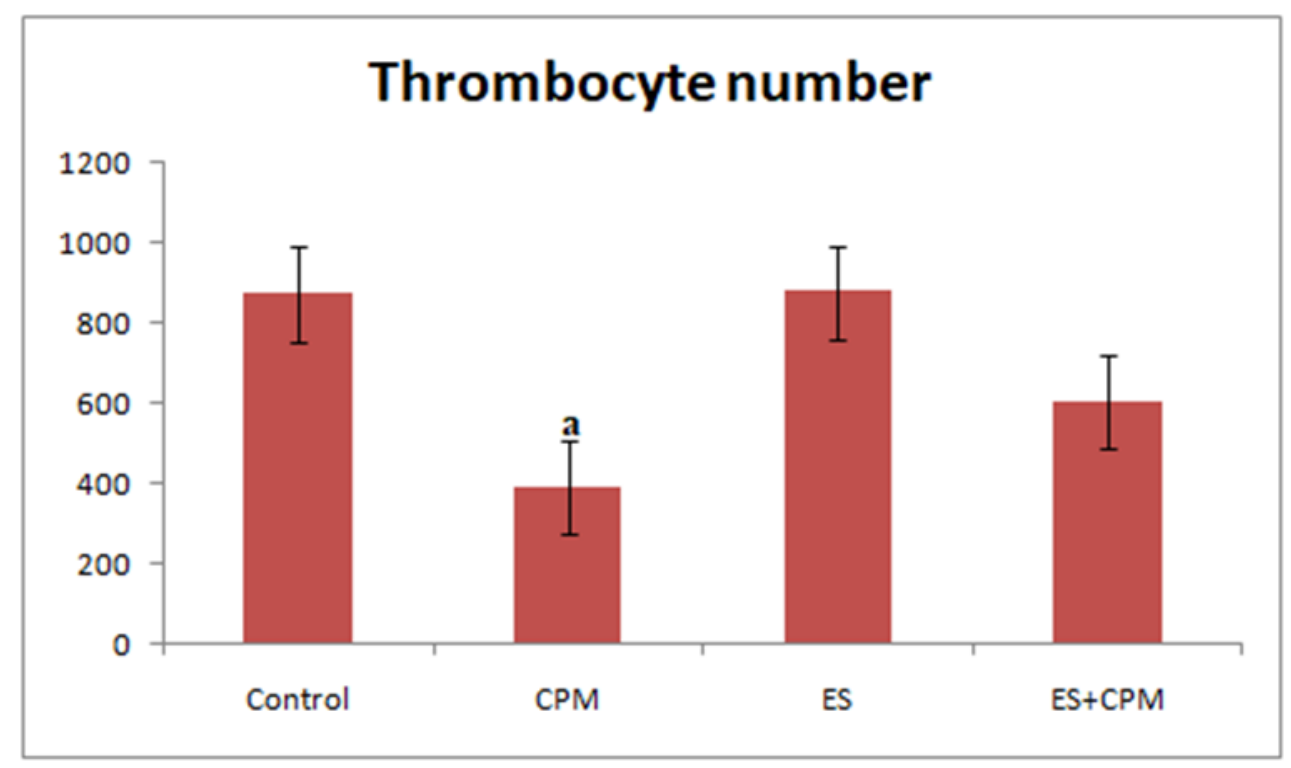

Figure 3. The number of peripheral thrombocytes in the existence of all groups $\left(\mathrm{X} 10^{3} / \mu \mathrm{L}\right) .{ }^{\mathrm{a}} \mathrm{p}<0.001$ significant difference compared to control 


\begin{tabular}{|c|c|c|}
\hline & $\begin{array}{l}\text { BŞEÜ Fen Bilimleri Dergisi } \\
7(2), 730-738,2020\end{array}$ & $\begin{array}{r}\text { BSEU Journal of Science } \\
\text { DOI: } 10.35193 / \text { bseufbd.677193 }\end{array}$ \\
\hline $\begin{array}{l}\text { BILECIK SEYH EDEBALI } \\
\text { UNIVERSITESI }\end{array}$ & & 58-7575 (http://dergipark.gov.tr/bseufbd) \\
\hline
\end{tabular}

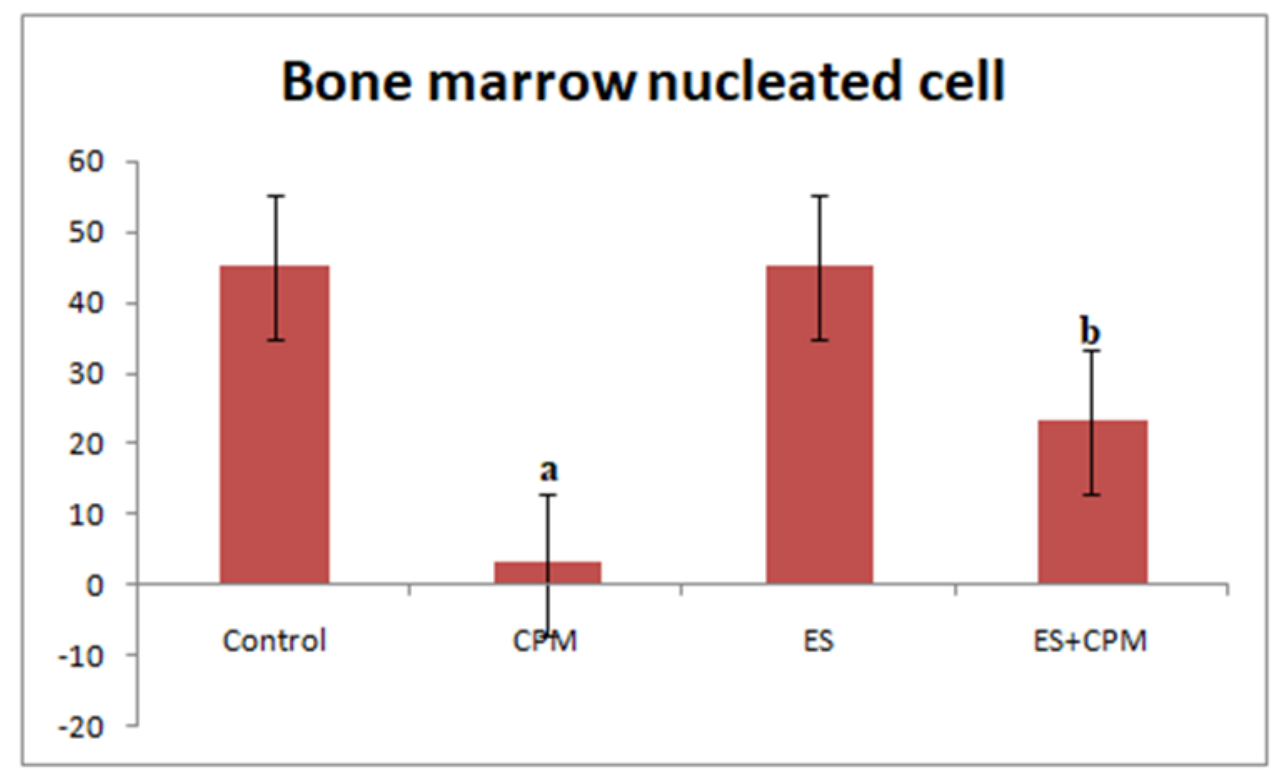

Figure 4. The number of bone- marrow-nucleated cells in the existence of all groups $\left(\mathrm{X} 10^{3} / \mu \mathrm{L}\right){ }^{\mathrm{a}}{ }^{\mathrm{a}}<0.001$ significant difference compared to control; ${ }^{\mathrm{b}} p<0.05$ significant difference compared to control

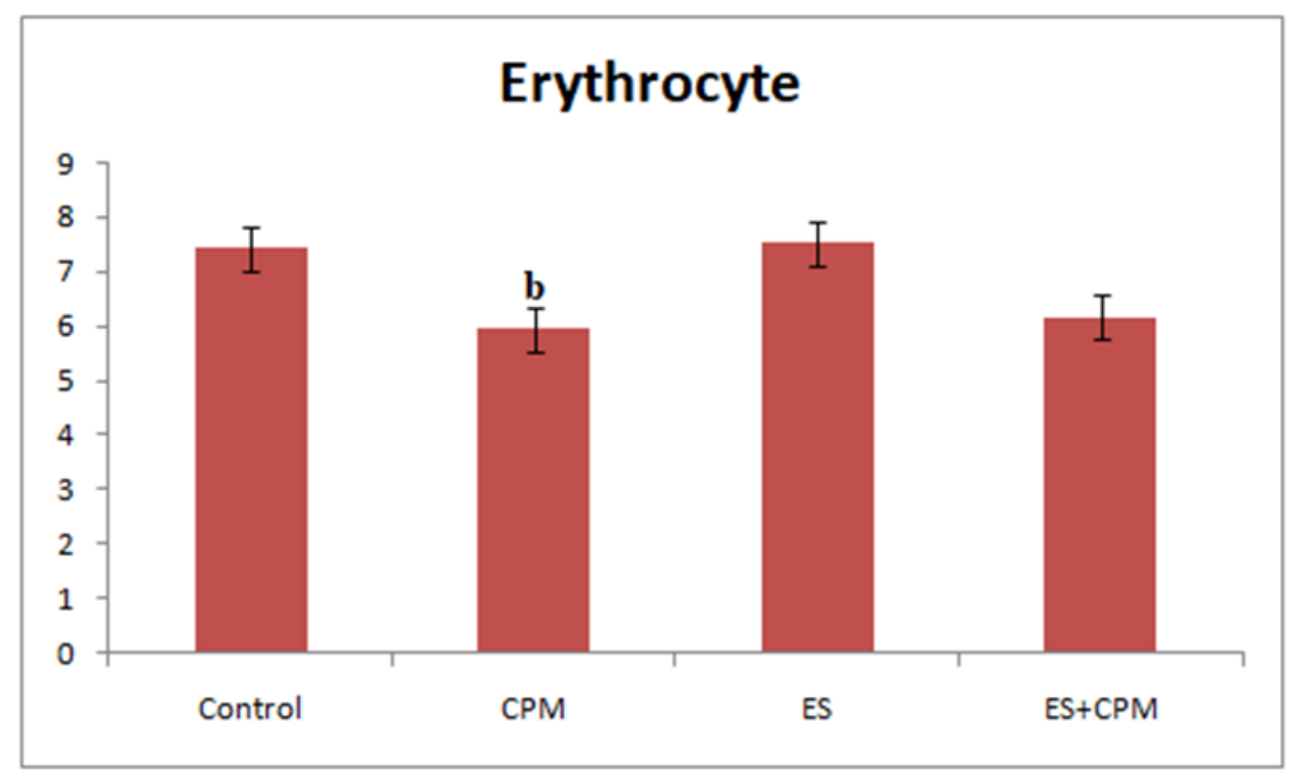

Figure 5. The number of erythrocytes cells in the existence of all groups $\left(\mathrm{X} 10^{6} / \mathrm{mm}^{3}\right) .{ }^{\mathrm{b}} p<0.05$ significant difference compared to control 


\begin{tabular}{|c|c|c|}
\hline & $\begin{array}{l}\text { BŞEÜ Fen Bilimleri Dergisi } \\
7(2), 730-738,2020\end{array}$ & $\begin{array}{r}\text { BSEU Journal of Science } \\
\text { DOI: } 10.35193 / \text { bseufbd.677193 }\end{array}$ \\
\hline $\begin{array}{l}\text { BILECIK SEYH EDEBALI } \\
\text { UNIVERSITESI }\end{array}$ & & 58-7575 (http://dergipark.gov.tr/bseufbd) \\
\hline
\end{tabular}

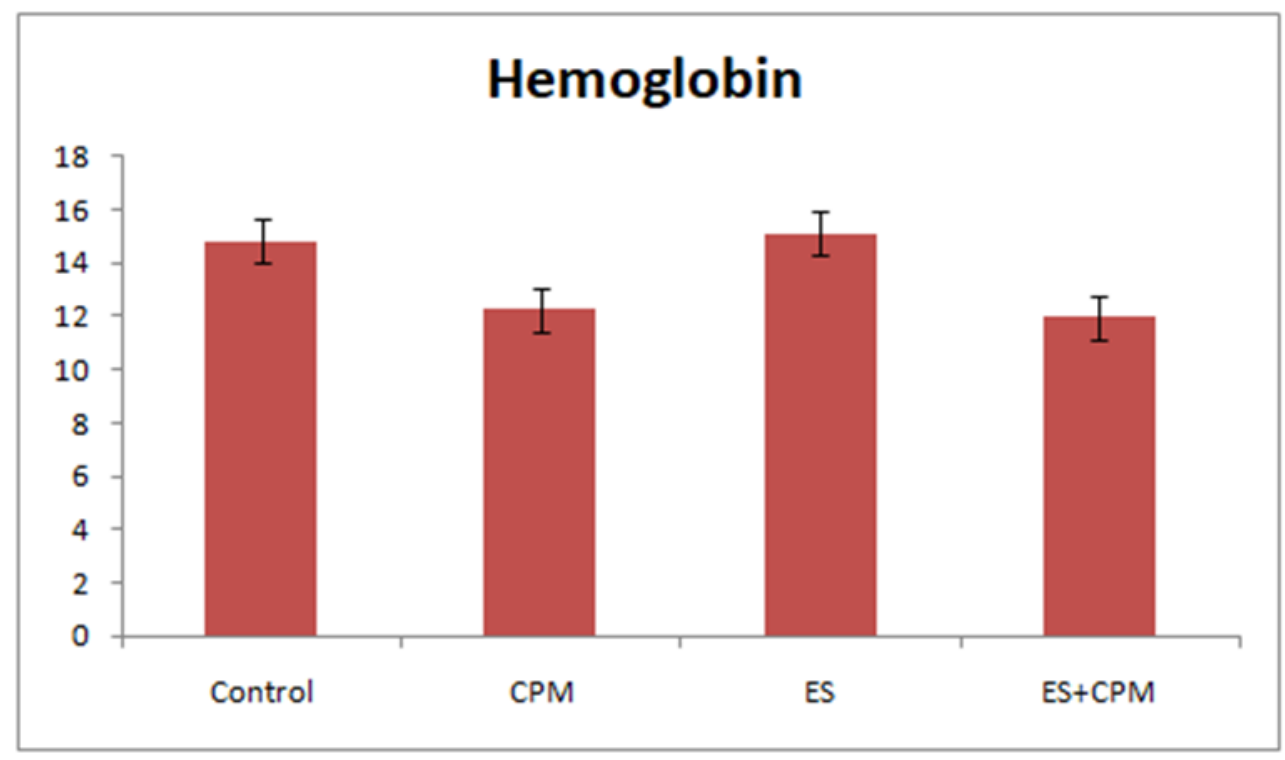

Figure 6. The number of hemoglobin the existence of all groups $(\mathrm{g} / \mathrm{dL})$

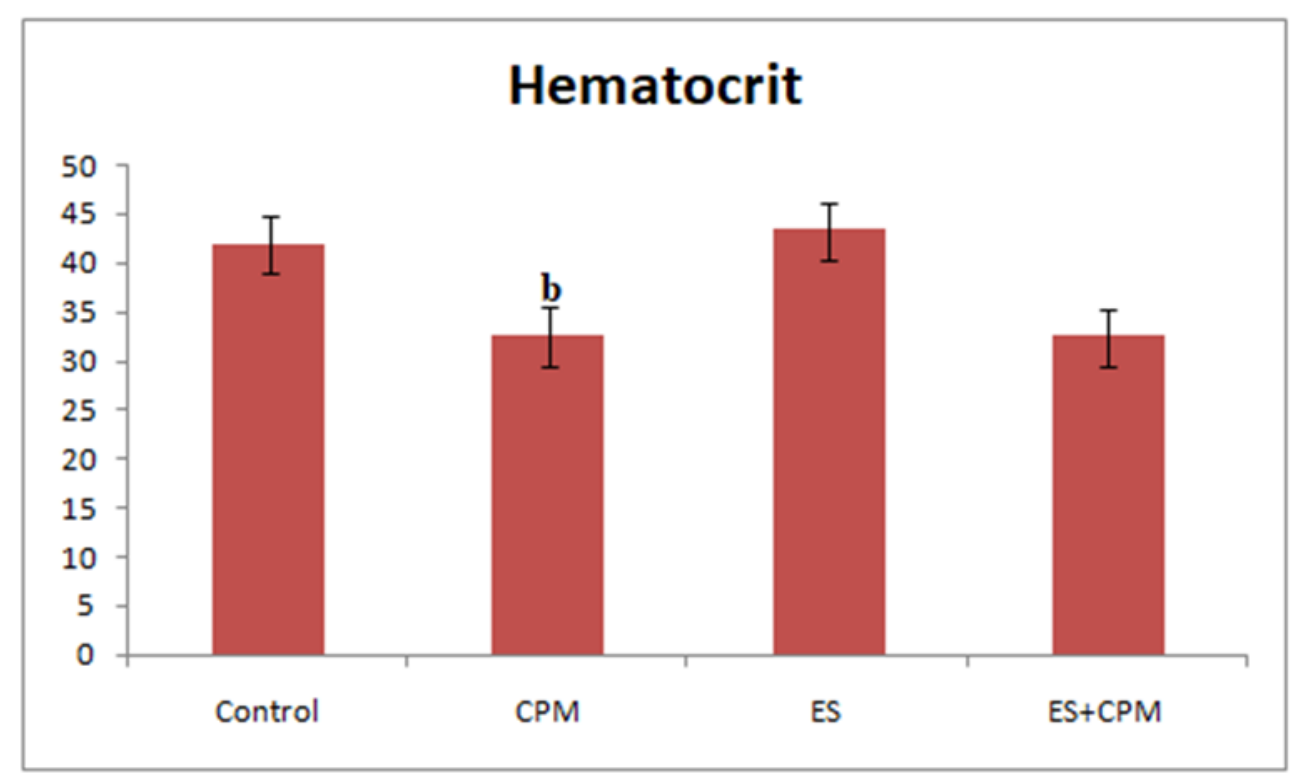

Figure 7. The number of hematocrit the existence of all groups $(\%) .{ }^{\mathrm{b}} p<0.05$ significant difference compared to control

\section{RESULTS}

The chemotherapeutic practicality of alkylating agents is closely related to their capability to type a diversity of DNA adducts which can reasonably change DNA structure or function or both at the same time as far as their cytotoxic effect on the cells are concerned. A large number of them are known to go through a rather intricate activation process before they are able to make reactive intermediates happen. The preliminary activation reaction as regards CPM achieved through the microsomal oxidation system in the liver generates 4-hydroxy CPM, a cytotoxic metabolite, diffusing from hepatocytes into plasma before they could be travel in the whole body. Then, 4-hydroxy CPM is transformed into cytotoxic metabolites like PAM and ACR. This situation results in myelosuppression $[11,12]$, which we know to be a chief potential toxic and dose-limiting adverse effect of CPM. 
By acting upon not just cyclic but also inter-mitotic cells, CPM leads to cross-linking of DNA and inhibition of DNA synthesis, which in turn, usually depletes immune component cells [13]. One study reports that $150 \mathrm{mg} / \mathrm{kg}$ CPM lowered the leukocyte numbers by $92 \%$, the platelet numbers by $54 \%$, and the bone marrow cell numbers by $94 \%$ [14]. In the same vein, a single dose of CPM injection caused leukocyte counts to go down [15]. Moreover, $\mathrm{CP}(40 \mathrm{mg} / \mathrm{kg})$ given to baboons has caused a temporary fall in White Blood Cell count [16]. Another experimental study emphasizes that CP (20 and $40 \mathrm{mg} / \mathrm{kg}$ ) may have a mutagenic effect upon the spleen and the bone marrow [17]. In a previous study, we demonstrated that $200 \mathrm{mg} / \mathrm{kg} \mathrm{CP}$ administration reduced significantly the numbers of erythrocyte (20\%), leukocyte (96\%), platelet (41\%), and hemoglobin (21\%), and hematocrit [18]. Trasler et al. [19] referred to the effects of erythrocyte, leukocyte, and bone marrow cell count in that they decreased dramatically when the CPM was given in high doses to the mice. In our study, we witnessed a noteworthy reduction in the number of erythrocytes, leukocytes $(97 \%)$, platelet $(45 \%)$, hemoglobin, hematocrit, and bone marrow nucleated cells $(93.6 \%)$ in the $200 \mathrm{mg} / \mathrm{kg}$ CPM group when compared to the control one. Our study results are remarkably consistent with those reported in the literature.

As for ES, it is a natural combination of triterpene saponins that is obtained from the seeds of Aesculus Chinensis Bge. or Aesculus wilsonii Rehd, largely consisting of A, B, C, and D escin (Figure 1). Mounting evidence suggests that administering ES intravenously results in anti- anti-oxidant [10,20], inflammatory [8], and antiedematous effects [21]. Our study is an original one in that while there are many studies into oral and intravenous effects of ES upon the liver, inflammation, and intestinal damage, no studies have been made as regards the protective effects of ES upon bone marrow, blood cell toxicities. Our study is an original one in that while there are many studies into the effects of ES upon the liver [10], inflammation [8], and intestinal damage (whether orally or intravenously), we do not come across any studies into the protective effects of ES upon bone marrow and blood tissue toxicities. In our study, in the group given CPM alone, we observed a reduction in the number of leukocytes, thrombocytes, erythrocytes, hemoglobin, and bone marrow cell counts as $97 \%, 45 \%, 20 \%, 21 \%$, and $93 \%$, respectively when compared to the control group. These rates were of high statistical significance. On the other hand, in the group given both CPM and $1 \mathrm{~m} \mathrm{mg} / \mathrm{kg} \mathrm{ES}$, the reduction in the number of leukocytes, thrombocytes, erythrocytes, hemoglobin, and bone marrow cell counts was $18 \%, 31 \%, 19 \%, 20 \%$, and 49\%, respectively when compared to the group given CPM alone. These rates were also of high statistical significance. Therefore, ES appears to be toxic neither for bone marrow nor blood cells on its own while CPM is already known to be toxic for bone marrow, leukocytes, and platelets. Based on our study results we conclude that ES may provide protection against the toxic effects of CPM. We, therefore, believe that ES is a potentially effective drug to be used in treating CPM-related damage, which can help prevent damage or treat CPM toxicity. Finally, we suggest that further studies should be conducted in order to discover the underlying mechanism of how ES protects against CPM toxicity.

\section{REFERENCES}

[1] Ayhanci, A., Heybeli, N., Sahin, İ. K., Cengiz, M. Myelosuppression and Oxidative Stress Induced by Cyclophosphamide in Rats: The Protective Role of Selenium. Adlyaman Üniversitesi Fen Bilimleri Dergisi, 9(2), 252-265.

[2] Kumari, J., Shaoo, P. K. (2005). Effects of cyclophosphamide on the immune system and disease resistance of Asian catfish Clarias batrachus. Fish Shellfish Immunolology, 19: 307-316..

[3] Shah, A. S., Wakade, A. S., Juvekar, A. R. (2008). Immunomodulatory activity of methanolic extract of Murraya koenigii (L) Spreng leaves. Ind J Exp Biolology, 46 (7): 505-509.

[4] George, K. S., Rajesh, R., Sunil Kumar, S., Sulekha, B., Balaram, P. (2008). A polyherbal ayurvedic drug Indukantha Ghritham as an adjuvant to cancer chemotherapy via immunomodulation. Immunobiology, 213:641-649

[5] Langford, C. A. (1997). Complications of cyclophosphamide therapy. Eur Arch Otorhinolaringol, 254:6572.

[6] Manda, K., \& Bhatia, A. L. (2003). Prophylactic action of melatonin against cyclophosphamide-induced oxidative stress in mice. Cell Biol. Toxicolology, 19:367-372. 
[7] Kumar, K. B. H., Kuttan, R. (2005) Chemoprotective activity of an extract of Phyllanthus amarus against cyclophosphamide induced toxicity in mice. Phytomedicine, 12:494-500.

[8] Fu, F., Hou, Y., Jiang, W., Wang, R., Liu, K. (2005). Escin: inhibiting inflammation and promoting gastrointestinal transit to attenuate formation of postoperative adhesions. World J. Surg,. 29, 1614-1620.

[9] Sirtori, C.R. (2001). Aescin: pharmacology, pharmacokinetics and therapeutic profile. Pharmacol. Res,. 44, 183-193.

[10] Cengiz, M., Kutlu, H. M., Peker Cengiz, B., Ayhanc1, A. (2020). Escin attenuates oxidative damage, apoptosis and lipid peroxidation in a model of cyclophosphamide-induced liver damage. Drug and Chemical Toxicology, 1-8.

[11] Cengiz, M., Yeşildağ, Ö., Ayhanci, A. (2018). Siklofosfamid Nedenli Hematoksisite Üzerine Karvakrolün Sitoprotektif Etkileri. Türkiye Tarımsal Araştırmalar Dergisi, 5(2), 125-130.

[12] Liang, J., Huang, M., Duan, W., Yu, X. Q., Zhou, S. (2007). Design of new oxazaphosphorine anticancer drugs. Curr Pharm Design, 13:963-978.

[13] George, K. S., Rajesh, R., Sunil-Kumar, S., Sulekha, B., Balaram, P. (2008). A polyherbal ayurvedic drugIndukantha Ghritham as an adjuvant to cancer chemotherapy via immunomodulation. Immunobiology, 213:641-649.

[14] Ayhanci, A., Yaman, S., Appak, S., Gunes, S. (2009). Hematoprotective effect of seleno-L-methionine on cyclophosphamide toxicity in rats. Drug and Chemical Toxicology, 32:4, 424-428.

[15] Fraiser, L. H., Kanekal, S., Kehrer, J. P. (1991) Cyclophosphamide toxicity: characterizing and avoiding the problem. Drugs, 42:781-795.

[16] Schuurman, H. J., Smith, H. T., Cozzi, E. (2005). Tolerability of cyclophosphamide and methotrexate induction immunosuppression in nonhuman primates. Toxicology, 213:1-12.

[17] Moore, F. R., Urda, G. A., Krishna, G., Theiss, J. C. (1995). An invivo/ invitro Method for Assessing Micronucleus and Chromosome Aberration Induction in Rat Bone Morrow and Spleen. 1. Studies with Cyclophosphamide. Mutation Research/Environmental Mutagenesis and Related Subjects, 335 (2): 191-199.

[18] Cengiz, M. (2018). Hematoprotective effect of boron on cyclophosphamide toxicity in rats. Cell Mol. Biol., (Noisy le Grand). 64 (5) 62-65.

[19] Trasler, J. M., Hales, B.F., Robaire, B. (1987). A time-course study of chronic paternal cyclophosphamide treatment in rats: effects on pregnancy outcome and themalere productive and hematologic systems. Biology of Reproduction, 37(2):317-26.

[20] Hu, X.M., Zeng, F.D. (2004). Protective effects of sodium beta-aescin on ischemia reperfusion injury in rat brain. Acta Pharm. Sin., 39 (6), 419-423.

[21] Jiang, N., Xin, W., Wang, T. et al. (2011). Protective effect of aescin from the seeds of Aesculus hippocastanum on liver injury induced by endotoxin in mice. Phytomedicine, 18(14), 1276-1284. 